\title{
3D6 and 4B3: Recombinant expression of two anti-gp41 antibodies as dimeric and secretory $\lg \mathrm{A}$
}

\author{
David Reinhart ${ }^{1,2^{*}}$, Robert Weik ${ }^{2}$, Renate Kunert ${ }^{2}$ \\ From 22nd European Society for Animal Cell Technology (ESACT) Meeting on Cell Based Technologies \\ Vienna, Austria. 15-18 May 2011
}

\section{Background}

Sexually transmitted diseases are predominantly acquired via mucosal membranes of the rectal or genital tract during sexual intercourse. This major port of virus entry is naturally defended by the humoral immune response, with immunoglobulin A (IgA) as the primary antibody class to elicit mucosal immunity. Dimeric IgA (dIgA) reaches the luminal side of mucosal tissues by transcytosis through epithelial cells lining the mucosa. In a first step, dIgAs specifically bind to the basolaterally expressed polymeric immunoglobulin receptor (pIgR) on epithelial cells. For release of IgAs on the luminal side the extracellular portion, termed secretory component (SC), remains attached to the antibody to form secretory $\operatorname{IgA}(\mathrm{sIgA})[1,2]$.

One example of a sexually transmitted disease is the human immunodeficiency virus (HIV) which annually infects several million individuals on a global scale and potentially leads to the acquired immunodeficiency syndrome (AIDS). Although current therapies can reduce disease progression in infected individuals, no cure is yet available or within reach in near future. As a consequence increased attention is now being paid to develop drugs that could prevent virus acquisition.

3D6 and 4B3 are two monoclonal antibodies (mAb) which have originally been isolated as IgG1 isotype from seroconverted HIV-1 patients and bind to the principal immunodominant domain of gp41. In the course of this project both mAbs were isotype switched to IgA1. Recombinant $\mathrm{CHO}$ cell lines were established for the production of 3D6 and 4B3 as dimeric as well as secretory IgA. While dIgA were expressed by a single cell line, sIgA are produced by a biochemical association of

\footnotetext{
* Correspondence: David.Reinhart@boku.ac.at

'Department of Biotechnology, Institute of Applied Microbiology, University

of Natural Resources and Life Sciences, Vienna, Austria

Full list of author information is available at the end of the article
}

dIgA with SC. Both dIgA and sIgA variants were characterized and the contribution of the heavily glycosylated SC on IgA stability will be investigated.

\section{Antibody expression}

MAbs 3D6 and 4B3 (IgG1) were developed at the Institute of Applied Microbiology [3,4]. Isotype switching was performed by substitution of the original heavy chain constant region with that for IgA1 (GenBank Accession Number 184743). For their recombinant expression as dIgA three plasmids were generated containing the coding region of either heavy chain, light chain or joining (J) chain. The latter one should increase dimerization of IgA monomers. Recombinant $\mathrm{CHO}$ clones were selected whereas high producers were isolated by applying the dihydrofolate reductase (dhfr) system.

Assembly of 3D6 and 4B3 as sIgA is intended by an in vitro biochemical association of dimeric IgA with human secretory component (hSC). Thus, $\mathrm{CHO}$ cell lines which solely express hSC were established by co-transfection of two plasmids containing the coding region for hSC and dhfr, respectiviely.

\section{Cultivation temperature greatly influences productivity}

Mammalian cells are commonly cultivated at $37^{\circ} \mathrm{C}$. In order to investigate the effect on $\mathrm{mAb}$ secretion, clones expressing 3D6-dIgA and 4B3-dIgA were propagated at sub-physiological temperatures. It was observed that temperature markedly impacts final IgA quantities in culture supernatants. Product titers of clones expressing 3D6-dIgA were almost 3-fold increased when incubated at $33{ }^{\circ} \mathrm{C}$ as compared to $37^{\circ} \mathrm{C}$. Furthermore, cultivation of $4 \mathrm{~B} 3$ - dIgA-expressing clones at $33^{\circ} \mathrm{C}$, rather than at $37{ }^{\circ} \mathrm{C}$, resulted in end titers which were approximately 13-fold increased. 
Table 1 Purification scheme developed for isolation of 3D6 and 4B3 dlgA.

\begin{tabular}{|c|c|c|c|c|}
\hline \multirow[t]{2}{*}{ STEP } & \multirow[t]{2}{*}{ EQUIPMENT } & \multirow[t]{2}{*}{ PROCEDURE } & \multicolumn{2}{|c|}{ RECOVERY } \\
\hline & & & $\begin{array}{l}\text { 3D6 } \\
\text { dlgA }\end{array}$ & $\begin{array}{r}4 \mathrm{~B} 3 \\
\operatorname{dlg} \mathrm{A}\end{array}$ \\
\hline Ultra/Diafiltration & $\begin{array}{l}\text { Kvick Start UDF Cassette, } \\
\text { Millipore, } 30 \mathrm{kD}\end{array}$ & $\begin{array}{c}\text { Harvested cell culture supernatant containing dlgA is concentrated and buffer } \\
\text { exchanged against PBS, pH 7.4 }\end{array}$ & $\begin{array}{l}>95 \\
\%\end{array}$ & $\begin{array}{l}>95 \\
\%\end{array}$ \\
\hline $\begin{array}{l}\text { Lectin Affinity } \\
\text { Chromatography }\end{array}$ & $\begin{array}{l}\text { Immobilized Jacalin, } \\
\text { Thermo Scientific }\end{array}$ & $\begin{array}{l}\text { UDF retentate is immobilized onto a lectin affinity resin. After a washing step, } \\
\text { bound product is eluted by applying } 1.5 \mathrm{M} \text { D-galactose in PBS, pH } 7.4\end{array}$ & $\begin{array}{l}98.7 \\
\%\end{array}$ & $\begin{array}{c}106.1 \\
\%\end{array}$ \\
\hline Ultra/Diafiltration & $\begin{array}{l}\text { Kvick Start UDF Cassette, } \\
\text { Millipore, } 30 \mathrm{kD}\end{array}$ & The eluate is buffer exchanged against $20 \mathrm{mM}$ Tris, $10 \mathrm{mM} \mathrm{NaCl}$, pH 8.5 & $\begin{array}{l}>95 \\
\%\end{array}$ & $\begin{array}{l}>95 \\
\%\end{array}$ \\
\hline $\begin{array}{l}\text { Anion Exchange } \\
\text { Chromatography }\end{array}$ & $\begin{array}{l}\text { DEAE Sepharose FF, GE } \\
\text { Healthcare }\end{array}$ & $\begin{array}{l}\text { The retentate is applied onto the anion exchanger. Post washing with } 100 \mathrm{mM} \\
\mathrm{NaCl} \text { product is eluted from the resin using } 20 \mathrm{mM} \text { Tris, } 200 \mathrm{mM} \mathrm{NaCl}, \mathrm{pH} 8.5\end{array}$ & $\begin{array}{l}88.4 \\
\%\end{array}$ & $\begin{array}{c}86.7 \\
\%\end{array}$ \\
\hline $\begin{array}{l}\text { Hydrophobic } \\
\text { Interaction } \\
\text { Chromatography }\end{array}$ & $\begin{array}{l}\text { Phenyl-Sepharose 6FF } \\
\text { low sub, GE Healthcare }\end{array}$ & 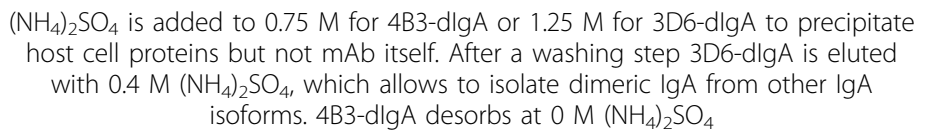 & $\begin{array}{c}44.1 \\
\%\end{array}$ & $\begin{array}{c}59.1 \\
\%\end{array}$ \\
\hline
\end{tabular}

\section{Purification of recombinant dlgA}

The two established mAb-expressing cell lines secrete dIgA at different quantities: The best clone producing 3D6-dIgA achieved a mean specific productivity of 59.1 $\pm 14 \mathrm{pg} / \mathrm{cell}$ "day (pcd). Conversely, the highest 4B3-dIgA secreting clone reaches a mean specific productivity of $0.6 \pm 0.4 \mathrm{pcd}$. Hence, an increased amount of host cell proteins is present in cell culture supernatants of 4B3dIgA as compared to 3D6-dIgA. Therefore, we elaborated a purification protocol which allows the recovery of both dimeric IgAs at a greatly enhanced purity. The purification procedure is shown in table 1 .

\section{Formation of secretory IgA}

Secretory IgA can be assembled in vitro due to the natural affinity of dimeric IgA for secretory component and vice versa (5). Initially, supernatants from recombinant cell lines expressing hSC, 3D6-dIgA or 4B3-dIgA were buffer exchanged against PBS. Subsequently, sIgA formation was performed by incubation of hSC with $\operatorname{dIgA}$ at $25^{\circ} \mathrm{C}$ for 3 hours at different molar ratios. However, applying a molar ratio of $1: 1$ is commonly described as optimal [5]. The association of 3D6-dIgA or 4B3-dIgA with hSC was successfully verified by SDS-PAGE following Western blotting (data not shown). Conjugation of the immunoblot was performed with a mouse antihuman secretory component antiserum (Sigma) and detected via an anti-mouse IgG1 antiserum (Sigma).

\section{Conclusions}

The anti-HIV-1 mAbs 3D6 and 4B3 were isotype switched and could successfully be expressed as dIgA in stably transfected $\mathrm{CHO}$ cells. Furthermore, continuous product secretion was obtained for at least 20 passages in spinner flasks.

Cultivation of the recombinant cell lines at different temperatures revealed that their product expression can markedly be influenced: 3D6-dIgA expression was nearly triplicated by shifting the temperature from $37^{\circ} \mathrm{C}$ to 33 ${ }^{\circ} \mathrm{C}$. Applying the same conditions, 4B3-dIgA product secretion was nearly 13 -fold increased.

A purification protocol was developed which allows the recovery of the dIgAs 3D6 and 4B3 in highly pure fractions. Furthermore, the elaborated scheme enables the isolation of dimeric 3D6 from its various high molecular weight isotypes.

Secretory IgA of both 3D6 and 4B3 can successfully be produced by mixing dimeric IgA with human secretory component.

\section{Acknowledgement}

Funding from the European Community's Seventh Framework Programme (FP7/2002-2013) under grant agreement №201038, EuroNeut-41.

\section{Author details}

'Department of Biotechnology, Institute of Applied Microbiology, University of Natural Resources and Life Sciences, Vienna, Austria. ${ }^{2}$ Polymun Scientific Immunbiologische Forschung $\mathrm{GmbH}$, Vienna, Austria.

Published: 22 November 2011

\section{References}

1. Snoeck V: The IgA system: a comparison of structure and function in different species. Vet Res 2006, 37(3):455-67.

2. Bonner A, Perrier C, Corthésy B, Perkins SJ: Solution structure of human secretory component and implications for biological function. $J$ Biol Chem 2007, 282(23):16969-80, Epub 2007 Apr 11.

3. Buchacher A, Predl R, Strutzenberger K, Steinfellner W, Trkola A, Purtscher M, Gruber G, Tauer C, Steindl F, Jungbauer A, et al: Generation of human monoclonal antibodies against HIV-1 proteins; electrofusion and Epstein-Barr virus transformation for peripheral blood lymphocyte immortalization. AIDS Res Hum Retroviruses 1994, 10(4):359-69.

4. Kunert R, Rüker F, Katinger H: Molecular characterization of five neutralizing anti-HIV type 1 antibodies: identification of nonconventional $\mathrm{D}$ segments in the human monoclonal antibodies $2 \mathrm{G} 12$ and 2F5. AIDS Res Hum Retroviruses 1998, 14(13):1115-28.

5. Crottet $P$, Corthésy $B$ : Secretory component delays the conversion of secretory IgA into antigen-binding competent $F\left(a b^{\prime}\right) 2$ : a possible implication for mucosal defense. J Immunol 1998, 161(10):5445-53.

doi:10.1186/1753-6561-5-S8-P56

Cite this article as: Reinhart et al:: 3D6 and 4B3: Recombinant expression of two anti-gp41 antibodies as dimeric and secretory IgA. BMC Proceedings 2011 5(Suppl 8):P56. 